\title{
STOCKHOLM \\ NATURAL RADIOCARBON MEASUREMENTS II
}

\author{
H. GöTE ÖSTLUND \\ Radioactive Dating Laboratory, Geological Survey of Sweden, Stockholm \\ This paper is a list of the radiocarbon datings of geologic and archaeologic \\ samples made during 1958 after the dating apparatus had been installed at the \\ Geological Survey. It is a direct continuation of the first dating list (Östlund, \\ 1957a). Some of the results of geophysical interest, measurements of a few \\ sea water samples, have been published separately (Fonselius and östlund, \\ 1959); others will follow.
}

\section{INTRODUCTION}

Technique and standards.-The techniques used for the preparation of pure carbon dioxide and the proportional counting setup have been described earlier (Östlund, 1957b), but in addition some further operations have been introduced. Tauber and de Vries (1958) and Olson and Broecker (1958) have pointed out the danger of contamination of old samples in situ by the precipitation of younger humus. Following their experience, all samples which might have been exposed to the slightest danger of that kind are boiled in $2 \%$ sodium hydroxide solution, washed carefully, boiled in dilute sulfuric acid, and finally washed again. This treatment has been considered to be especially important for peat samples of greater age, but in a few cases it has been omitted, and this fact is stated in the actual sample descriptions.

At present two proportional counters are in operation, the older $1-1$ and the new 0.5-1 tubes. The latter has a working pressure of 3 bar, a background of 2.0 counts $/ \mathrm{min}$ and gives $9.6 \mathrm{C}^{14}$-counts $/ \mathrm{min}$ from modern carbon. As previously, each sample is counted for at least two 20-hour periods, and most of the samples have been run in both counters.

The modern standard is still oak wood grown about A.D. 1850 in Djurgården, Stockholm $\left(59^{\circ} 20^{\prime} \mathrm{N}\right.$ Lat, $18^{\circ} 08^{\prime} \mathrm{E}$ Long), and its counting rate is corrected for decay up to 1958 . The age figures in this paper, as well as in our first list, are thus unaffected by the industrial combustion of fossil fuels (the so-called Suess effect) and nuclear bomb activity.

The U. S. National Bureau of Standards Natural Radiocarbon Standard gives a counting rate which is $104.5 \pm 0.5 \%$ of our age-corrected oak standard.

The $\mathrm{C}^{13} / \mathrm{C}^{12}$ ratio of each sample of purified carbon dioxide has been measured mass-spectrometrically. The counting rate of each sample has been corrected accordingly before calculating the age. All calculations were made in the same manner as was described in our first dating list. In each error is included the statistical uncertainties of the measurements of the sample and of related standard and background figures, together with the small error in the $\mathrm{C}^{13}$ determination and the half-life of radiocarbon, $5568 \pm 30$ years.

ACKNOWLEDGMENTS

A generous grant from the King Gustaf VI Adolf Foundation for Swedish 
Culture made it possible to move the apparatus into completely repaired and well equipped laboratory rooms, for which I would like to express my respectful thanks.

As usual I am indebted to Mr. Ryhage and his staff at Karolinska Institutet, Stockholm, for making the $\mathrm{C}^{13}$ determinations.

Most of the routine operation of the whole equipment has been made by Miss Vivan Jacobson, and the work by her and the other members of the staff is hereby appreciated.

The laboratory is run by the Royal Academy of Antiquities and the Geological Survey of Sweden, through supervision by the Swedish C14 Board. The cost of the radiocarbon dating work is nearly covered by an annual grant from public funds.

\section{SAMPLE DESCRIPTIONS}

\section{GEOLOGIC SAMPLES-SWEDEN}

\section{A. Submorainic Samples}

\section{St-325. Ale, Norrbotten}

A thin layer of peat, consisting of Tomentypnum nitens, below $5 \mathrm{~m}$ of till and resting on fine sand, at Ale, $20 \mathrm{~km} \mathrm{~W}$ of Luleå, Norrbotten $\left(65^{\circ} 37^{\prime} \mathrm{N}\right.$ Lat, $21^{\circ} 42^{\prime} \mathrm{E}$ Long), Sweden. The submorainic position and the fossil content of the peat, indicating a swamp in probably arctic environment, strongly suggest an interglacial age, or possibly early Würm interstadial (Fromm, 1958). Coll. 1957 and subm. by E. Fromm, Geological Survey of Sweden. Comment: the limited quantity of the sample prohibited chemical treatment for removal of younger humus. We thus prefer to give the minimum age in spite of the fact that a definite $\mathrm{C}^{14}$ age could have been calculated.

\section{St-324. Frösö, Jämtland}

$2820 \pm 135$

Charcoal from a layer of charred wood at Herke, SSE of the church of Frösö, on the island of Frösön in Lake Storsjön, Jämtland $\left(63^{\circ} 10^{\prime} \mathrm{N} \mathrm{Lat,} 14^{\circ}\right.$ $33^{\prime}$ E Long), Sweden. The layer was 1 to $2 \mathrm{~cm}$ thick and covered by $80 \mathrm{~cm}$ of moraine, which was supposed to be in primary position. Coll. 1944 and subm. by B. Asklund, Geological Survey of Sweden. Comment: the result clearly indicates that the moraine had slid.

\section{St-328. Kil, Värmland}

Spruce wood (Picea) found at a depth of $30 \mathrm{~m}$ under glaciofluvial deposits in the delta at Fryksta, $2 \mathrm{~km} \mathrm{~N}$ of Kil, Värmland $\left(59^{\circ} 32^{\prime} \mathrm{N}\right.$ Lat, $13^{\circ}$ 20’ E Long), Sweden. Coll. 1958 by E. Alsterlind, Kil ; subm. by Jan Lundqvist, Geological Survey of Sweden. Comment: the find is evidently interglacial or possibly interstadial. A similar sample from the same locality has been dated previously (St-113, Östlund, 1957a), also giving infinite age.

\section{B. Postglacial Strandlines}

\section{St-339. Hägared, Halland}

$1020 \pm 80$

Sample of sand, containing a fraction of organic material, mostly mould, and covered by a drift-sand dune at Hägared, $2.7 \mathrm{~km} \mathrm{~S}$ of the church of 
Tvååkra, Halland $\left(57^{\circ} 01^{\prime} \mathrm{N}\right.$ Lat, $12^{\circ} 24^{\prime} \mathrm{E}$ Long $)$, Sweden. The sample is situated at the postglacial transgression limit, here at $16 \mathrm{~m}$ above present sealevel; formation of the dune was supposed to have begun in the 17th century. Coll. 1958 and subm. by H. Tullström, Geological Survey of Sweden. Comment: Evidently the $\mathrm{C}^{14}$ age does not apply to any of the known events, or else the dune was formed earlier than expected. No attempt has been made to extract humus by sodium hydroxide treatment, since the organic material itself seemed to be humus. On the other hand, it is not likely that a modern contamination could be completely responsible for the very low age in comparison with the transgression.

St-379. Fajans Tile-Works, Halland

$8200 \pm 140$

Sample of a humified peat layer, $1.0 \mathrm{~km} \mathrm{E}$ of Falkenberg, Halland $\left(56^{\circ}\right.$ $54^{\prime} \mathrm{N}$ Lat, $12^{\circ} 31^{\prime} \mathrm{E}$ Long), Sweden. The upper surface of the layer, $0.11 \mathrm{~m}$ thick, is situated $4.64 \mathrm{~m}$ above the present sealevel. It is covered inter alia by clay-gyttja and rests on $0.73 \mathrm{~m}$ of partly humus-containing silt with boulders, which belong to a fossil strandline. The silt is underlain by weathered, varved glacial clay. Coll. 1958 and subm. by H. Tullström, Geological Survey of Sweden.

\section{St-333. Sörevik, Blekinge}

$9000 \pm 140$

Layer of drift mud, principally consisting of pine wood, occurring $3.5 \mathrm{~m}$ below surface of the bottom and $4.0 \mathrm{~m}$ below the present water level, at the island of Senoren, Ramdala parish, in the Baltic Sea, ESE Karlskrona $\left(56^{\circ} 07^{\prime}\right.$ $20^{\prime \prime} \mathrm{N}$ Lat, $15^{\circ} 46^{\prime} 24^{\prime \prime} \mathrm{E}$ Long), Sweden. The layer of drift mud is only 5 $\mathrm{cm}$ thick, rests on sand, and is overlain by mud. Some $200 \mathrm{~m}$ farther out in the sea the drift mud continued to a depth of at least $7 \mathrm{~m}$ below present sealevel. According to pollen analysis, the zone boundary IX/VIII (Scanian system, Nilsson, 1935) is situated immediately below the drift mud layer. Other data, including diatom analyses, indicate that the boundary between Yoldia and Ancylus zones is situated approximately at the same level. Subm. by Björn Berglund, Department of Quaternary Geology, University of Lund.

\section{Postglacial Climatic History}

\section{Husvålen, Anjan, and Northern Dalarna series}

These series were made as a part of a study on postglacial variations of the upper limit of the Pinus forest, caused by climatic changes. All the samples consist of well preserved Pinus stumps revealed by erosion under the cover of present vegetation and peat, at altitudes above the present forest line. The distribution of the present-day Pinus and its relation to the fossil material is too complicated to be described here, but will be described elsewhere (Lundqvist, 1959). Coll. 1950-1958 and subm. by G. Lundqvist, Geological Survey of Sweden.

Husvålen. Pine wood on the alpine heath on the mountain Husvålen, $\mathrm{NE}$ of Ljungdalen, Härjedalen $\left(62^{\circ} 50^{\prime} \mathrm{N}\right.$ Lat, $12^{\circ} 53^{\prime} \mathrm{E}$ Long), Sweden. Altitudes 800 to $850 \mathrm{~m}$.
St-308. Husvålen 1
$7780 \pm 120$
St-354. Husvålen 2
$5310 \pm 125$ 
St-357. Husvålen 3

St-361. Husvålen 4

Anjan. Pine wood on the alpine heath or in the upper birch (Betula) forest on the mountains Skäckerfjällen, NE of the Anjan tourist hotel, Jämtland $\left(63^{\circ} 45^{\prime} \mathrm{N}\right.$ Lat, $12^{\circ} 38^{\prime} \mathrm{E}$ Long), Sweden. Altitudes 500 to $600 \mathrm{~m}$

St-380. Anjan 1

$6110 \pm 100$

St-394. Anjan 5

$5390 \pm 125$

St-395. Anjan 7

St-382. Anjan 9

$5530 \pm 125$

St-383. Anjan 10

$5290 \pm 105$

St-384. Anjan 15

$5630 \pm 130$

Northern Dalarna (Dalecarlia). Pine wood from altitudes above the forest limit on mountains at the northernmost tip of the County of Dalarna $\left(62^{\circ} 10^{\prime} \mathrm{N}\right.$ Lat, $12^{\circ} 20^{\prime} \mathrm{E}$ Long), Sweden. Altitudes above $900 \mathrm{~m}$. The locations are close to the places listed below.

St-396. Hävlingskläppen

$7330 \pm 130$

St-397. Lake Grötvallsjön

$6840 \pm 140$

St-398. Grövelsjön, $E$ of the tourist hotel

$6520 \pm 170$

St-320. Mustvallen, Jämtland

$4630+100$

Stump of fir from a bog at alt. $820 \mathrm{~m}$ on Storfjället in the Oviksfjällen (Ovik mountains) $3 \mathrm{~km} \mathrm{~W}$ of Mustvallen, Jämtland $\left(62^{\circ} 57^{\prime} \mathrm{N}\right.$ Lat, $13^{\circ} 57^{\prime} \mathrm{E}$ Long), Sweden. The present forest limit is at $650 \mathrm{~m}$ at this point. The find indicates a warm period and may be considered together with the Husvålen, Anjan, and Northern Dalarna series. Coll. 1957 and subm. by Jan Lundqvist, Geological Survey of Sweden.

St-313. Färsksjön, Blekinge

$\mathbf{3 9 1 0}+\mathbf{8 0}$

Pine wood from stubs in situ on the bottom of a bay in the NW part of Lake Färsksjön, Jämjö parish, Blekinge $\left(56^{\circ} 09^{\prime} 20^{\prime \prime} \mathrm{N}\right.$ Lat, $15^{\circ} 51^{\prime} 45^{\prime \prime} \mathrm{E}$ Long), Sweden. The depth of water is 60 to $80 \mathrm{~cm}$. Pollen analysis is impossible, the stubs being situated above the sedimentation boundary, but evidently the conditions indicate a change toward moister climate since the trees were growing (Nilsson, in press). Coll. and subm. by Björn Berglund, Department of Quaternary Geology, University of Lund.

\section{Toppeladugård series, Skåne}

Sandy peat and clay-gyttja of Allerød age from Toppeladugård $\left(55^{\circ} 36^{\prime}\right.$ N Lat, $13^{\circ} 22^{\prime}$ E Long), $14 \mathrm{~km}$ SSE of Lund, Scania, Sweden. The Allerød layer consists of a thin layer of brown, sandy peat, "Allerød mould", overlain by two layers of clay-gyttja or lime-gyttja, (upper and lower "Allerød gyttja"), which are interbedded by purer clay. The Allerød layer is covered by Upper Dryas Clay and underlain by clayey sand and boulder-clay (Holst, 1906, 1908; Nilsson, 1935, p. 430, 474, and in press). The "Allerød mould" may be 
assumed to date the beginning of the Allerød period. Coll. 1958 and subm. by Tage Nilsson, Department of Quaternary Geology, University of Lund.

St-341. Allerød mould

St-345. Allerød gyttja, organic

$12,000 \pm 200$ the $\mathrm{C}^{14}$ age is a little higher than expected, especially in comparison with St-34l, but this might be due to the fact that the sample consisted of lacustrine sediments, i.e. largely remnants of living matter that incorporated carbonate of the lake water.

St-342. Allerød gyttja, carbonate

$13,600 \pm 400$

Carbonate of the same portion as St-345. (The age corrected to standardized isotopic composition.) Comment: the result makes it highly likely that the carbon system of the former lake was "older" than contemporary air and terrestrial carbon. This is surely due to leaching of sedimentary carbonate minerals by the feed-water of the lake.

\section{Recurrence Surfaces in Peat Bogs}

\section{Ockelbo series, Gästrikland}

Samples of peat from a bog at Gammelboning, Ockelbo, $7 \mathrm{~km} \mathrm{~N}$ of Kungsberg, Gästrikland $\left(60^{\circ} 49^{\prime} \mathrm{N}\right.$ Lat, $16^{\circ} 30^{\prime} \mathrm{E}$ Long), Sweden. Dating of the samples was made as part of a current investigation on the time-scale of recurrence surfaces in Sweden. Coll. 1957 and subm. by C. Larsson, Geological Survey of Sweden.

St-319. Ockelbo 4

$830 \pm 65$

Wood from a layer of stubs, $75 \mathrm{~cm}$ helow the surface, supposed to belong to a recurrence surface.

St-351. Ockelbo 6

$1330 \pm 80$

Peat from a supposed recurrence surface $185 \mathrm{~cm}$ below the surface. Comment: both of these results are in discordance with our knowledge of similar cases. The work is being continued.

\section{E. Various Geologic Samples}

\section{St-305. Bohus, Västergötland}

$820 \pm 65$

Oak wood from the scar of a landslide, called "Jordfallet" ("The Soil Falls") at Bohus, Västergötland, in the Göta Älv valley $\left(57^{\circ} 51^{\prime} \mathrm{N}\right.$ Lat, $12^{\circ}$ $00^{\prime} \mathrm{E}$ Long), Sweden. The former soil surface was revealed $5 \mathrm{~m}$ under the overthrust clay and contained large fractions of the stump of an oak, which had apparently been growing at the time of the earth slide and had been broken by it. The outermost intact year rings were taken to date the event. Coll. and subm. by B. Järnefors, Geological Survey of Sweden.

\section{GEOLOGIC SAMPLES-OTHER COUNTRIES}

St-377. Zagazig, Egypt

Brown coal from a well at Wadi Pumping station near Zagazig, in the Nile Valley delta, Sharkia Province ( $30^{\circ} 33^{\prime} 10^{\prime \prime}$ N Lat, $31^{\circ} 38^{\prime} 26^{\prime \prime}$ E Long), 
Egypt. The sample (Nr SH 43 at the Department of Geology, Faculty of Science, Cairo University) was taken from a coal bed, $1.5 \mathrm{~m}$ thick, at a depth of $72 \mathrm{~m}$ below the derrick level of the well. The coal rested on a layer of medium sand and was supposed to be of post-Lower-Paleolithic age. Coll. 1958 and subm. by Rushdi Said, Department of Geology, Cairo University, Egypt.

\section{ARCHAEOLOGIC SAMPLES-SWEDEN}

\section{A. Lappland and Neighboring Provinces}

St-340. Soukolojärvi

$710 \pm 75$

Wood from an "ackja" (snow boat, hollowed-out trunk sledge), exposed by digging a ditch in the village of Soukolojärvi, Övertorneå, Norrbotten $\left(66^{\circ}\right.$ $29^{\prime}$ N Lat, $23^{\circ} 37^{\prime}$ E Long), Sweden. Pollen analysis gives "Picea time," i.e. younger than 1000 B.c. but older than latest Medieval (Wahlberg, 1956). Subm. by A. Oldeberg, Museum of National Antiquities, Stockholm.

\section{Saivorova series, Lappland}

In the neighborhood of the Laponian sacrificial grove of Saivorova, Gällivare parish, $25 \mathrm{~km} \mathrm{WSW}$ Kiruna, Lappland, there are four pits, $1 \mathrm{~m}$ deep $\left(67^{\circ} 48^{\prime} \mathrm{N}\right.$ Lat, $19^{\circ} 45^{\prime} \mathrm{E}$ Long), Sweden. In the bottoms of these were charcoal and fire-burned boulders, 10 to $30 \mathrm{~cm}$ in diameter. The pits are surrounded by circular banks, consisting of brittle-burned stones and charcoal. The pits have presumably been used as cooking pits, and the banks around each of them have been formed by cleaning out the pit before each time of use. Thus the coal underneath the bank indicates the time of its first use, and the coal at the bottom of the pit originates from its last time of use. Charcoal from Pit No. 3 has been dated previously (St-152 Gällivare, Östlund, 1957a). It has been included in the list below for the sake of completeness. Coll. 1954 and subm. by H. Hvarfner, Royal Office of National Antiquities, Stockholm.

$\begin{array}{llr}\text { St-393. } & \text { Pit No. 1 }: \text { Bottom of the pit } & 950 \pm 75 \\ \text { St-353. } & \text { Pit No. 2: Underneath the bank } & 1260 \pm 100 \\ \text { St-152. } & \text { Pit No. 3: Bottom of the pit } & 1150 \pm 65 \\ \text { St-346. } & \text { Pit No. 4: Underneath the bank } & 1175 \pm 90 \\ \text { St-349. } & \text { Pit No. } 4: \text { Bottom of the pit } & 980 \pm 120\end{array}$

\section{Nikkaluokta series, Lappland}

Charred wood from two of the pits between the House of the Club of the Mountain Men and the Chapel in Nikkaluokta, Gällivare parish, $50 \mathrm{~km} \mathrm{~W}$ of Kiruna, Lappland $\left(67^{\circ} 51^{\prime}\right.$ N Lat, $19^{\circ} 02^{\prime}$ E Long), Sweden. The pits have not yet been subject to careful archaeologic examination; they have been supposed to be habitation sites, but there are also indications that they might be naturally formed. Coll. 1954, and subm. by E. Manker, Nordiska Museet, Stockholm, and H. Hvarfner, Royal Office of National Antiquities, Stockholm.

St-3 17. Pit No. 1: Bottom layer

St-352. Pit No. 2: Bottom layer

$$
\begin{aligned}
& 2075 \pm 85 \\
& 1360 \pm 105
\end{aligned}
$$

St-373. Gäddede, Jämtland

$4360 \pm 105$

Bone fragments of elk from the Stone Age settlement T61 at Lake Kvarnbergsvattnet, Gäddede, Frostviken, Jämtland $\left(64^{\circ} 30^{\prime} \mathrm{N}\right.$ Lat, $14^{\circ} 09^{\prime} \mathrm{E}$ 
Long), Sweden. Archaeologic dating: not older than Neolithic time. Coll. 1947 and subm. by S. Janson, Office of National Antiquities. Charcoal (St-187 Gäddede; Östlund, 1957a) from the same settlement was dated as $3115 \pm 75$ yrs B.P. Comment: only the organic carbon of the bone was used for analysis. Any contamination in the bone would make the $\mathrm{C}^{14}$ age lower, since no lacustrine sediments were possible. From that point of view the radiocarbon age is at least a minimum age. The habit of the Lapps of taking old, dry fir wood for fire, together with the fact that the charcoal of St-187 was in very good condition, means that any possible error would make the settlement younger, not older, than the charcoal. At the moment, the only possible explanation of the discrepancy is that the settlement was inhabited either twice or continuously during the long time span. Further samples from the settlement will be measured.

St-306. Färila

$655 \pm 65$

Wood from a double canoe, found sunken by heavy stones at a depth of $3 \mathrm{~m}$, on the bottom of Lake Breasen, Färila, Hälsingland $\left(61^{\circ} 5 \mathrm{l}^{\prime} \mathrm{N}\right.$ Lat, $15^{\circ}$ $40^{\prime}$ E Long), Sweden. This highly unusual specimen deserved radiocarbon dating, in spite of lack of archaeologic connection. Coll. 1929 and subm. by A. Viksten, Färila.

\section{B. Southern Sweden}

\section{St-372. Björnlunda, Södermanland}

$1185 \pm 70$

Wood from primitive wooden plough, found in the soil on the farm Tibble, Björnlunda, Södermanland $\left(59^{\circ} 06^{\prime} \mathrm{N}\right.$ Lat, $17^{\circ} 08^{\prime} \mathrm{E}$ Long), Sweden. According to pollen analysis the sample belongs to the Iron Age. Subm. by R. Jirlov, State College, Västerås. Comment: another portion of this specimen has been dated by the Uppsala $\mathrm{C}^{14}$ laboratory (U-45, $1125 \pm 70$; Olsson, 1959).

\section{Fiskeby series, Östergötland}

Resin caulkings from various graves in a grave field at Fiskeby, $4 \mathrm{~km}$ NW of Norrköping. Östergötland ( $58^{\circ} 36^{\prime} \mathrm{N}$ Lat, $16^{\circ} 06^{\prime} \mathrm{E}$ Long), Sweden. The grave field includes 520 inhumations with finds which form a chronological series from the last phase of the Bronze Age to the second half of the Viking Age. In addition to the resin caulkings, many of the graves contain only artifacts which cannot yet be dated archaeologically but which are of importance for further work. In Sweden, however, there is a serious lack of archaeologic material that can be connected with the first two periods of the Iron Age $(500$ to 100 B.C.). The resin was used as tightening material in bark boxes filled with cremated bone. It is hoped that radiocarbon dating of the caulkings may also answer the question whether the break in the series of finds indicates an intermission in the use of the burial place or is caused by other reasons. The work on the Fiskeby material will be continued. The samples were collected in 1951-1952 and subm. by P. Lundström, Museum of National Antiquities, Stockholm, who also made a preliminary description of the material (Lundström, 1952a, b).
St-317. Fiskeby 1. Grave No. 248
$2510 \pm 90$
St-321. Fiskeby 2. Grave No. 217
$2505 \pm 85$ 
St-326. Fiskeby 3. Grave No. 536

St-327. Fiskeby 4. Grave No. 556

$2070 \pm 85$

St-385. Fiskeby 5. Grave No. 366

$1980 \pm 100$

St-390. Fiskeby 7. Grave No. 317

$2635 \pm 90$

Comment: none of these datings indicates the first two periods of the Iron Age.

\section{Älgsjön series}

Samples of gyttja from the bottom sediments of Lake Älgsjön, Bjälbo, Östergötland $\left(58^{\circ} 24^{\prime} \mathrm{N}\right.$ Lat, $15^{\circ} 00^{\prime} \mathrm{E}$ Long), Sweden, taken to check the continuity of agriculture by means of pollen and radiocarbon analysis. Subm. by Staffan Helmfrid, Institute of Geography, University of Stockholm. Comment: the age figures should be used with caution, since the material has incorporated carbon dioxide of lake water, which might have been of high apparent age.

St-318. Älgsjön A

$2070 \pm 110$

From the 450-cm level at the beginning of the Secale curve, about $40 \mathrm{~cm}$ above the beginning of the Picea curve.

St-309. Älgsjön B

$860 \pm 110$

From the $280-\mathrm{cm}$ level to secure the chronology of the diagram.

\section{St-366. Roma, Gotland}

$1800 \pm 100$

Bone from horse, "Gotland russ," found by archaeologic survey of Roma Airfield, Gotland (57 $30^{\prime}$ N Lat, $15^{\circ} 30^{\prime}$ E Long), Sweden. No archaeologic dating, but two thin-butted stone axes were found very close to the bones. Thus it was interesting to know whether the connection between the horse bones and the axes was real. Coll. 1957 and subm. by Greta Arwidsson, Institute of Archaeology, University of Stockholm, and E. Nylén, County Museum of Gotland, Visby. Comment: of the bones, which were in good condition, only the organic carbon was used for analysis. This material being sensitive to organic contamination, the age figure is less reliable, but since possible contaminating material is younger than the sample, the $\mathrm{C}^{14}$ age may be accepted as a true minimum age.

St-374. Stenbrohult, Småland

$905 \pm 65$

Worked piece of wood, part of construction of unknown kind at a depth of $1.2 \mathrm{~m}$ below the surface in a peat bog near Sannaböke, Stenbrohult, Småland $\left(56^{\circ} 35^{\prime} \mathrm{N}\right.$ Lat, $14^{\circ} 10^{\prime} \mathrm{E}$ Long), Sweden. No archaeologic dating (Oldeberg, in press). Coll. and subm. by A. Oldeberg, Museum of National Antiquities, Stockholm.

\section{Ancient Buildings}

St-371. Tingstad, Östergötland

$845 \pm 70$

Wood from a supporting log in the north portal of Tingstad medieval church, Östergötland $\left(58^{\circ} 32^{\prime} \mathrm{N}\right.$ Lat, $16^{\circ} 18^{\prime} \mathrm{E}$ Long), Sweden. From architectural-historical considerations, dated at the beginning of 15 th century. Subm. by K. von Schmalensee, Norrköping. 
Fragment of a fir board, part of a window frame found during the restoration of the Vadstena Convent buildings, Östergötland (58 $27^{\prime}$ N Lat, $14^{\circ} 53^{\prime}$ E Long), Sweden. The window belongs to a secular building, a King's Manor, which was taken over by the Mother Convent of the Bridgittines on its establishment at the end of the 14th century (Anderson, 1958). The Manor is supposed to have been built early in the 13th century. Coll. and subm. by I. Anderson, Museum of National Antiquities, Stockholm.

\section{St-381. Hossmo, Småland}

$1020 \pm 75$

Wood from an oak log in the Romanesque church of Hossmo, Småland, $\left(56^{\circ} 38^{\prime} \mathrm{N}\right.$ Lat, $16^{\circ} 14^{\prime} \mathrm{E}$ Long), Sweden. From architectural evidence, presumably dated at the end of the 12th century. Subm. by I. Anderson, Museum of National Antiquities, Stockholm. Comment: the number of years that elapsed between growth of the dated wood and cutting of the tree is unknown, and the visible rings were rather narrow. Thus a number between 0 and 400 should be subtracted from the $\mathrm{C}^{14}$ age to give the age of the artifact.

\section{ARCHAEOLOGIC SAMPLES-OTHER COUNTRIES}

\section{St-315. Forum Romanum, Rome, Italy}

$2525 \pm 75$

Pieces of charcoal from a layer in the road foundation of Sacra Via, within Forum Romanum, Rome ( $41^{\circ} 54^{\prime} \mathrm{N}$ Lat, $12^{\circ} 27^{\prime} \mathrm{E}$ Long), Italy. The filling material consists partly of remnants from the Gallic catastrophe of 386 B.c. Subm. by E. Gjerstad, Swedish Institute, Rome, Italy.

\section{St-338. Erimi, Cyprus}

$4480 \pm 150$

Charcoal from Erimi, Cyprus $\left(34^{\circ} 40^{\prime} \mathrm{N}\right.$ Lat, $32^{\circ} 55^{\prime} \mathrm{E}$ Long) belonging to the Erimi Culture, which has been archaeologically dated between 3200 and 2800 B.C. (Dikaios, 1953, p. 314-315). Coll. and subm. by P. Dikaios, Department of Antiquities, Nicosia, and transmitted to the laboratory by $O$. Vessberg. Comment: other samples from the same site have been dated earlier (Östlund, $1957 \mathrm{a})$; St-202, $4630 \pm 80$; and St-203, $4540 \pm 80$. All three radiocarbon datings are close to their average $4570 \pm 60$ but, on the other hand, differ appreciably from the archaeologic estimate.

\section{Sotira series, Cyprus}

Charcoal from two huts belonging to the Sotira culture in Sotira, Cyprus $\left(34^{\circ} 42^{\prime} \mathrm{N}\right.$ Lat, $32^{\circ} 51^{\prime} \mathrm{E}$ Long). The period has been archaeologically dated between 3400 and 3200 B.c. (Dikaios, 1953, p. 314-315). Coll. and subm. by P. Dikaios, Department of Antiquities, Nicosia, and transmitted to the laboratory by $\mathrm{O}$. Vessberg.

\section{St-350. Hut No. 12 \\ St-337. Hut No. 29}

$$
\begin{aligned}
& \mathbf{5 1 5 0} \pm 130 \\
& \mathbf{5 4 6 0} \pm 110
\end{aligned}
$$

Comment: in contrast with the Erimi series above, the archaeologic and radiocarbon datings check well. Even the slight difference between the two dates corresponds to stratigraphic order. 


\section{REFERENCES}

Anderson, I., 1958, Gården Vastenis och klostret i Watzstena [summ. in English]: Fornvännen, v. 53 , p. 258-271.

Dikaios, P., 1953, Khirokitia: Oxford, Oxford Univ. Press.

Fromm, Erik, 1958, Ett förmodat interglacialfynd nära Luleå [lecture abst.] : Geol. fören., Stockholm förh., v. 80, p. 137.

Fonselius, S., and Östlund, H. G., 1959, Natural radiocarbon measurements on surface water from the North Atlantic and the Arctic Sea: Tellus, v. 11, p. 77-83.

Holst, N. O., 1906, De senglaciala lagren vid Toppeladugård: Geol. fören. Stockholm förh., v. 28 , p. $55-89$.

1908, Efterskörd från de senglaciala lagren vid Toppeladugård: Sveriges geol. undersökning, ser. C, no. 210.

Lundqvist, G., 1959, Cl4-dated pine stumps from the high mountains of western Sweden [in Swedish, summ. in English]: Sveriges geol. undersökning, ser. C, no. 565

Lundström, P., 1952a, Gravfältsundersökningar vid Fiskeby 1951: Fornännen, v. 47, p. 120 1952b, Gravfältsundersökning vid Fiskeby 1952: Fornvännen, v. 47, p. 281

Nilsson, Tage, 1935, Die pollenanalytische Zonengliederung der spät- und postglacialen Bildungen Schonens: Geol. fören. Stockholm förh., v. 57, p. 385-562. Eiszeit. in press, Aktuelle

Oldeberg, A., in press, Träfynd i mossar: Fornvännen, v. 54.

Olson, E. A., and Broecker, W. S., 1958, Sample contamination and reliability of radiocarbon dates: New York Acad. Sci. Trans., ser. 2, v. 20, p. 593-604.

Olsson. Ingrid, 1959, Uppsala natural radiocarbon measurements I: Am. Jour. Sci., Radioc. Supp., v. 1, p. 87-102.

Östlund, H. G., 1957a, Stockholm natural radiocarbon measurements I: Science, v. 126, p. $493-497$.

1957b, Carbon dioxide proportional counting for natural radiocarbon measurements: Arkiv f. Kemi, v. 12, no. 6, p. 69-78.

Tauber, Henrik, and de Vries, Hessel, 1958, Radiocarbon measurements of Würm-interstadial samples from Jutland: Eiszeit. u. Gegenwart, v. 9, p. 69-71.

Wahlberg, E., 1956, Ackjafyndet från Soukolojärvi: Norrbotten, v. 1956, p. 81. 